\title{
SEXUALITY, DIVERSITY AND LAW: THE LEGAL PROTECTION OF SEXUAL EXPRESSIONS
}

\author{
SEXUALIDADE, DIVERSIDADE E DIREITO: A PROTEÇÃO JURÍDICA DAS \\ EXPRESSÕES SEXUAIS
}

Recebido: 09.03.2020

Aprovado: 18.04 .2020

\author{
Valéria Silva Galdino \\ Pós-doutora em Direito pela Universidade de \\ Lisboa. Doutora pela Pontifícia Universidade \\ Católica de São Paulo. Docente da Universidade \\ Estadual de Maringá do Centro Universitário de \\ Maringá. Advogada no Paraná; \\ E-MAIL: valeria@galdino.adv.br \\ LATTES: http:/ / lattes.cnpq.br/8121501433418182 \\ ORCID: https://orcid.org/0000-0001-9183-0672
}

\author{
Caio Eduardo Costa Cazelatto \\ Doutorando em Direito pela Universidade \\ Federal da Bahia. Docente no Centro \\ Universitário Uningá. Advogado. \\ E-MAIL: caio.cazelatto@hotmail.com \\ LATTES: http:/ /lattes.cnpq.br/0966325595710576 \\ ORCID:https://orcid.org/0000-0001-5190-8543
}

\begin{abstract}
The social and juridical contours attributed to the values and expressions of human sexuality are the constant target scientific discussions, especially when this attention is focused on sexual diversity. As a result of this, the present research had bibliographical and narrative reviews in order to investigate the legal protection of sexuality, above all, that related to the experience of sexual minorities. For that, the historical, conceptual and classificatory aspects about the theme were explored as well as sexuality, discussed as a fundamental right and personality, since its exercise is immanent to the human condition.
\end{abstract}

KEY WORDS: Human sexuality; Sexual diversity; Sexual minorities.

RESUMO: Os contornos sociais e jurídicos atribuídos aos valores e às expressões da sexualidade humana são alvos de constantes discussões científicas, especialmente quando essa atenção se direciona à diversidade sexual. Em virtude disso, a presente pesquisa teve como finalidade, a partir da revisão bibliográfica e narrativa, investigar a tutela jurídica da sexualidade, sobretudo, a que se relaciona com a vivência das minorias sexuais. Para isso, explorou-se os aspectos históricos, conceituais e classificatórios acerca da temática. Como também, discutiu-se a sexualidade enquanto um direito fundamental e de personalidade, tendo em vista que o seu exercício é imanente à condição humana.

PALAVRAS-CHAVE: Diversidade Sexual; Minorias sexuais; Sexualidade humana.

SUMÁRIO: 1 Introduction 2 On The Expressions Of Human Sexuality 3 Human Sexuality As A Fundamental Personality Right 4 Conclusion 5 Referências 6 Notas de Referência 


\section{Introduction}

Pluralism is one of the pillars of the current Brazilian democracy, in which diversity integrates the complex conception of society. Living within a social environment means living with differences, which may not always be well received by the community. As a result, public authorities should pay more attention to the protection of minorities and vulnerable groups, in order to have a differential treatment from the rest of the population.

In this reasoning, the recognition of freedom, as the free exercise of human sexuality, including freedom of affective-sexual orientation and gender identity, does not represent an act of "kindness" guaranteed by the Public Power, but a right.

Sexuality is seen as a set of related elements that go beyond what human beings believe to be natural or biologically created. It involves constant historical-cultural constructions and deconstructions - guided by social and legal control through power, that is, what is imposed and systematized as being correct by both the State and society - of sexual values. In this way, sexuality enrobes itself as one of the structuring characteristics of the person, being so intrinsic that it's present from the womb until the end of his/her existence.

With regard to legal norms, there is expressly no prohibition or limitation for their exercise. There are, on the other hand, norms that seek to create a more egalitarian society in general. In this respect, the Federative Republic of Brazil has as one of its foundations the promotion of everyone's welfare, without any kind of discrimination, according to the provisions in art. 3, IV, being that the principle of human dignity, provided for in art. 1, III, and the principle of equality, set forth in its art. 5, caput, demand social respect towards diversity, since it is regarded as an expression of private autonomy and self-determination.

Therefore, it is required from the legal sphere the appropriation of values and related goods with the sexual experience that matter to society, for the purposes of its protection and promotion. In fact, the expression of sexuality is governed by sociocultural rules within the context it finds itself in, which varies according to the place and the time it's analyzed, which is why its conceptualization varies from country to country, as well as, with each historical period.

In view of this, the delimitation of human sexuality and its legal protection was specifically investigated, specifically focusing on sexual minorities, such as lesbians, gays, bisexuals, pansexual and transgender. To this end, the following questions were explored: How is human sexuality constituted? What are its structuring elements? Is its practice a fundamental right and that of personality? Do sexual minorities have the legitimacy to exercise it freely?

To clarify these questions, the methodology will comprise, the narrative review and the bibliographical survey, which consists of critically and meticulously analyzing, what has already been produced and recorded about human sexuality and its legal protection in doctrinal reports, legislation and electronic documents.

\section{On The Expressions Of Human Sexuality}

Human sexuality presupposes an emphasis on the sexual act itself, however, it is a trans disciplinary and multifaceted issue that entails different controversies and covers a multitude of experiences that are biological, psychological and political in nature that encompass moral, cultural, ethical, religious, legal and social experiences present in the life of everyone from the womb, permeating their reflexes, even after death.

If in the previous centuries the exercise of sexuality played a secondary role in social deliberation, in the nineteenth century it came to occupy a preeminent place, relating basically

93 Revista Brasileira de Direito Animal, e -issn: 2317-4552, Salvador, volume 15, n. 02, p.79-93, Mai - Ago 2020 
to the reproduction of the human species as an animal instinct, a conception based on the orthodox biology of Darwinism and Christianity (LAWLOR, 1991, p. 37).

The rupture of this paradigm came mainly during the twentieth century, with the creation and improvement of contraceptive techniques and assisted human reproduction, derived from scientific and technological evolution, the feminist struggles and the LGBTQ movement for sexual freedom. In fact, the human beings differ from other animals in the awareness of themselves regarding their existence and by their notion of sociability, in which their instincts can be controlled and transformed through rationality, which is why the choice of companionship is directed much more by the pleasure of the relationship than by the instinctive need for reproduction.

With the constant mutation of sexual values, its conceptualization has become broader in character, diversified and not consensual. In this sense, we can find several attempts at defining it, and although we don't intended to point one as being correct and absolute or to synthesize it to a reductionist term, it is important to approach and compare the most widespread ones in the scientific milieu.

In the words of Anthony Giddens, sexuality is an attribute that every individual "[...] has or cultivates, no longer a natural condition that the individual accepts as a pre-established state of affairs" it's about "[...] a malleable aspect of the self, a point of connection between the body, self-identity and social norms" ${ }^{1}$ (GIDDENS, 1992, p. 25). Thus, however much sexuality is anchored in the materiality of the body it must be understood as a system that transcends the merely physiological.

Alain Tourraine, however, analyzes it under the perspective of happiness, warning that it is not "[...] reduced to a form of consumption, nor to an eroticism as its opposite. It is rather a call of the individual to himself, to his/her free creation, to pleasure, to his/her happiness." ${ }^{2}$ (TOURRAINE, 1998, p. 89).

According to the World Health Organization (WHO), sexuality is a central aspect of the human being, since it integrates the personality of each one. It establishes it as a basic necessity that cannot be disconnected from other aspects of life, being constituted by sex, gender, gender identity, sexual orientation, eroticism, pleasure, intimacy and reproduction, among other components (WORLD HEALTH ORGANIZATION, 2002).

Therefore, the understanding of sexuality as a construction of society represents the contraposition to sexual "essentialism," which holds that the human essence is dominated by animal impulses. It is moving towards a historical conception of what is, in reality, a "[...] complex network of social organization that organizes and models individual bodies and behaviors", 3 as Jefrey Weeks emphasizes (WEEKS, 2001, p. 43).

Above all, sexual expressions are basic to the full development of the individual, especially in regards to his/her personality, both because it is one of the most primordial manifestations related to pleasure, becoming dissociated from a sentient being, its relational and identity function.

In this regard, Sigmund Freud maintained that every person is guided by two innate drives, namely: sexuality and death. For him, the human being is sexual in nature, but for various reasons society seeks, constantly and historically, to repress these natural tendencies, which would cause a state of tension and internal conflict in the individual (FREUD, 1982).

In line with the Declaration of Sexual Rights from the World Association for Sexual Health, human sexuality can be described as "[...] a central aspect of the human being throughout life encompassing gender, identity and gender roles, sexual orientation, eroticism, pleasure, intimacy and reproduction." ${ }^{4}$ It's influenced by the interaction of biological, social, economic, political, cultural, legal, historical, religious and spiritual factors. (WAS, 2013).

94 | Revista Brasileira de Direito Animal, e -issn: 2317-4552, Salvador, volume 15, n. 02, p.79-106, Mai - Ago 2020 
One of the most characteristic traits of the sexual dimension is, therefore, its identity, since it covers the way in which the human being identifies him or herself physically, psychically, morally and socially. In other words, it runs from the most intimate essence to the most exposed aspects of the person. As a result of this search for an identity that will make him/her unique in the world he/she is in, the person takes on innumerable attributes that will compose and form the image that he/she longs for him/herself or that the society expects of this person, as in the name, pseudonym, marital status, physical and emotional appearance, voice, profession, ethnicity, reputation, behavior, educational level, economic status and, above all, sexual manifestations.

The integration of these characteristics composes the personal identity of the subject, which stands out in the legal environment as a right expressed by the person's power to demand recognition and respect for his/her individuality in the face of others, bound to a plurality of rights, which allow the free development of the personality, including the protection of psychophysical integrity and the protection of health and the power to dispose as one wishes of parts of one's own body. It is a question of "[...] man's ability to self-construct by estimating what defines him as a truly human being, the foundation of his dignity, the founding value of all his rights" ${ }^{5}$ (SIVERINO-BAVIO, 2014).

It's in the extension of the right to personal identity, coming from the sexual status or sexual identity, that sexuality is present in all expressions of the personality of the subject. One of the first characteristic of identification and differentiation among human beings occurs through the simple examination of the newborn's external genitalia. This is enough to put the baby into one of two categories, either male or female, boy or girl, and even masculine or feminine.

For Elimar Szaniawski, the right to a sexual identity, based on the right to selfdetermination, belongs to the body of norms related to the free development of personality and freedoms, such as freedom of movement, freedom to perform certain activities and freedom to self-determine (SZANIAWSKI, 2005, p. 170). Personality and freedom thus constitute the essential condition for human life. Each individual has the private autonomy to express his/her freedom in the way that suits him/her, as long as it does not cause injury or risk of obvious harm to another or to the collectivity.

As part of the totality of human existence, sexuality transcends any attempt that limits sexual identity, and it cannot be reduced only to stiff and outdated values. In this perspective, our identity diversity is revealed, encompassing homosexuality, bisexuality, heterosexuality, pansexuality, asexuality and transgendered, which include transsexuality and transvestibility. These are identities arising from the possibilities between the relationship of the elements that make up sexuality, especially sex, gender, gender identity and affective-sexual orientation.

The use of the term "sex" to refer generally to sexuality, sexual orientation, gender or gender identity is common, both in scientific arena and in people's daily lives, but they are not phenomena of the same nature.

In fact, sex constitutes the physical and biological aspects of the human body, which involves the genetic, gonadal, somatic and genital variables that result in the body characteristics of a male or female being. Nevertheless, it should be emphasized that the complexity of the human condition goes beyond dualities or binarisms, which is what happens with intersexuality, which can manifest itself in different ways, either because the gonads have intermediate characteristics between the two sexes, or because the genital tract does not match the chromosomal type (LIMA; TORALLES, FRASER, 2010, v. 1, p. 212). 
For the World Association for Sexual Health, sex is related to the set of characteristics that in animals and plants differentiates the male from the female, that is, "[...] the biological characteristics that define human beings as men or women" ${ }^{\prime 6}$ (WAS, 2013).

Tereza Rodrigues Vieira points out that the processes of sexual determination and differentiation in humans are intrinsically linked to the presence or absence of the $Y$ chromosome in the karyotype. The specialization of the gonads is the fundamental factor in sexual determination. The other differences between the sexes are secondary consequences caused by the hormones they produce (VIEIRA, 2009).

In addition to the biological attributions, the subject's biological sex is perceived as a categorical factor in determining the social, sexual and affective practices of the human being, which is why Vera Felicidade de Almeida Campos points out that the "[...] biological and anatomical aspects have become so important that sex has become a symbol, perhaps even an icon, for the human sexual dimension, for human sexuality"7 (CAMPOS, 1999).

Jaqueline Gomes de Jesus points out that this is determined by the "[...] size of their reproductive cells (small: sperm, therefore, male, large: ovum, hence female), and only that." 8 On the other hand, it is evident that "biologically speaking, this does not define the masculine or feminine behavior of people: culture does this" ${ }^{\prime \prime}$. For the author, while sex comes from the biological aspects, what we conceive as being a man or a woman are not the chromosomes or the genital conformation, but the self-perception and the way the person expresses him/herself socially. This refers to the gender, which comes from a social construction (JESUS, 2012, p. 6-7). The sex of the subject is thus enveloped by symbolic meanings of genre and becomes a categorical factor in determining the social and affective practices.

Thus, gender is a category of social analysis and the production of culture, which attributes value to roles, responsibilities, characteristics and behaviors through the dualism between the "feminine" or the "masculine", that is, "woman" or "man", where the conceptualization may vary not only from one territorial context to another, but over time as well.

Therefore, something that is defined as feminine in one place may not be in another, such as the skirt which in the Brazilian territory is exclusively attributed to women, whereas in Ireland and Scotland this attire, specifically the kilt, can be recognized as an exclusively a male symbol. Another example, before February 24, 1932, the electoral vote was markedly a political expression of man, and today this would be inconceivable to have such restriction based on gender.

Exploring gender means not only questioning the nature of biological determinisms, but also the normative values that characterize femininity and masculinity that constitute social relations.

The symbols of the feminine and the masculine that comprise the genre are assimilated in society "from the outside in", that is, from the process by which the person internalizes what has been learned and exalted as correct in its cultural arrangement. In this perspective, it is dominant, for example, in Brazilian culture, to be permissive towards men and repressive towards women.

The constitution of the genre, for Cristina Câmara, is basically based on four interrelated elements: cultural symbols, normative concepts, notion of politics and subjective identity, which refer "to the codified tradition, to the daily practices, and to the proposals of cultural innovation elaborated by the social groups"10 (CAMARA, 2002, p. 23).

This is easily illustrated in the representation of the feminine, in which the girl must have an affinity to pink; she must be gentle, helpful and sensitive. She must also be prepared, from an early age, to perform household activities, bear children and care for them and, be a

96 | Revista Brasileira de Direito Animal, e -issn: 2317-4552, Salvador, volume 15, n. 02, p.79-106, Mai - Ago 2020 
subordinate to her husband. Thus, the role revolves around "duty", while that of the boy is associated to freedom, as the provider of the family, "tough" and virile and free for his personal, sexual, professional growth and other aspects of his life.

For Marta Kohl Oliveira, each society creates legitimate ways of being a man and of being a woman, establishing certain hierarchies among these identities, in which:

[...] the individual performs external actions that will be interpreted by the people around him, according to culturally established meanings. From this interpretation it's possible for the individual to assign meanings to his own actions and to develop internal psychological processes that can be interpreted by himself from the mechanisms established by the cultural group and understood through the codes shared by the members of that group. (OLIVEIRA, 1993, pp. 38-39). ${ }^{11}$

It's with the social production of signs and functions, considered as feminine or masculine, and the stereotyped and standardized cultural practices that involve sexuality that individuals as social beings standardize themselves to be accepted and recognized in society.

Regarding this, the human being, since childhood, is taught to behave, appear and use a corresponding name to his/her biological sex, which was probably determined through an ultrasound, before birth or, at most, after childbirth and attributing it, from then on, the responsibility to follow the precept for boys to be "like this" and girls to be "like that". With this, the anatomical basis of the genitalia is the starting point for the sexual function of the person.

Whether the meaning given to the biological sex in regards to gender is compatible or not, is where the controversies lay surrounding gender identity, also called social sex. This can be understood as the personal and internal experience of each person's gender, including the personal sense of the body, and may involve, by free choice, the transformation of appearance or bodily function through medical and surgical procedures, as well as other gender expressions, such as clothes, speech, and mannerisms.

If on the one hand we have the categories of masculine or feminine, on the other we have how the subjects absorb these categories into their lives. Therefore, it's the perceived gender chosen by each person to be adopted within his or her intimate environment or public life, regardless of the physical sex, which shows that biological aspects alone are not sufficient for determining gender identity. It's about the "[...] self-perception of the subject; with the coincidence or divergence between the person's perception of him/herself and the identity that society (or the parents, the physicians, in his/her name) attributed to him/her"12 (LEON, 2014, p. 329).

In this sense, if an individual identifies with the gender that correlates with the his or her genital, that is, being biologically male and identifying with the male gender or being biologically female and identifying with the female gender, both will be classified as cisgenic. When it does not match the cultural expectation of sex/gender combination, it will be specified as a transgender (GOULART; NARDI, 2015, p. 1-2).

According to Jaqueline Gomes de Jesus the term transgender, being generic and comprehensive, is an "umbrella" concept, comprising in its configuration people who do not identify, to varying degrees, with the gender predetermined socially. Among the diversity of manifestations of gender identity, transversability and transsexuality are the most notorious, and although these sexual representations seem, at first, similar, such experiences do not mix (JESUS, 2012, p. 14). 
For Maria Helena Diniz, transsexuality is supported by the sexual condition of the one who disagrees with his/her own body's anatomy, identifying psychologically with the opposite gender. For her, the most striking trait of the transsexual is the non-acceptance of the person's own body structure, because he/she "[...] feels that he/she was born with the wrong body"13 (DINIZ, 2002, p. 231). However, it should be noted that gender re-assignment surgery does not make person transsexual. In this sense, the transsexual woman refers to every person who claims social and legal recognition as a woman, while the transsexual man is anyone who claims social and legal recognition as a man.

Transversability is marked by the simultaneous and mixed adaptation of the binarism of the genders, that is, of the feminine and masculine values by an individual man, which can be manifested through corporal modifications or behavioral representation. For the transvestite, there is no rejection of the genitalia, since this is part of the person's self-identification, as explained by Larrisa Pelucio:

Transvestite are people born with a genital sex and seek to add to their bodies symbols of what is socially sanctioned for gender binarism, without, however, wishing to mutilate their genitalia, with which they generally coexist without major conflicts (PELUCIO, 2006). ${ }^{14}$

Keila Simpson (president of the National Association of Transvestites and Transsexuals), Rodrigo Borba and Ana Cristina Ostermann (SIMPSON, 2011, p. 114-115) state that although they show greater affinity towards female symbols (name, dress, body appearance, etc.), transvestites do not want to be men or women, they recognize themselves as transvestites and claim, in addition to dualities, the gender identity "transvestite".

Another element of sexuality that has a strong impact on the identification of LGBTQ minorities is the affective-sexual orientation defined by the Yogyakarta Principles (an international document aimed at promoting human sexuality) as "a reference to each person's capacity to have a deep emotional, affective and/or sexual attraction towards individuals of a different gender, the same gender or of more than one gender"15 (PRINCÍPIOS DE YOGYAKARTA, 2006).

It has been maintained, in the popular and even scientific scope, that the identification of the individual in relation to sexual orientation is conditioned towards the identification of the sex of the chosen person, in relation to the person who chooses, when in reality, it is constituted by the identification of the gender of the object of desire, whether masculine or feminine.

It is possible to infer, therefore, that the verification of the affective-sexual orientation of the human being occurs from the relationship between his/her gender with that of the partner's, and not by its biological sexes, as it's usually explored. From the analysis of the affective-sexual orientation we have several sexual identities that result, in which the most common are heterosexuality, homosexuality, bisexuality, asexuality and pansexuality.

The biological traits, therefore, are not factors that determine the subjectivity of the human being, nor their perception of belonging to a certain sexual identity. Sexuality is socially constructed by the sum of an individual, the cultural and historical realities surrounding the person, manifested in different ways, and where there is no one "correct" form of sexual expression and another "deviant" one, in view that experience, in a free and full way, composes the totality of the human personality.

\section{Human Sexuality As A Fundamental Personality Right}

98 | Revista Brasileira de Direito Animal, e -issn: 2317-4552, Salvador, volume 15, n. 02, p.79-106, Mai - Ago 2020 
When integrating the process of the development of contemporary subjectivity, we see that sexual signs have modified the roles of the human body, which is constantly subjected to a "political anatomy" and to the "mechanics of power" that shape it, deconstruct it and recompose it in accordance with disciplinary authorities.

Overcoming control and the interference of society and the State with the private autonomy of the individual, especially with regard to sexuality, is manifested in the struggles for legal recognition of certain essential goods to guarantee the minimum essentials towards the full maintenance and promotion of dignity, existence and satisfaction of sexual minorities.

Sexuality and what it encompasses constitutes the fundamental basis of the human condition insofar as it is present, directly or indirectly, in all manifestations of the personality. The spectra of meanings correlate with a number of particularities of the intimate, psychic and moral experience of the subject, being based not only on a right to sexuality, but on a number of rights that are branched out in the face of the sexual sphere or influenced by them.

Because of the complexity and impossibility of having an exact definition on the subject, sexuality rights represent, by virtue of their "general" character, legal protection beyond the individual or a sexually vulnerable group, according to their gender identity or their affectivesexual orientation, encompassing any sexual diversity that does not infringe the rights of others.

For Roger Raupp, any right of this kind, in order to be democratic, must be based on constitutional principles, especially on equality, freedom and dignity, since it is from these that other norms are constituted and unfold, as is the case with right to sexual freedom; the right to sexual autonomy, sexual integrity and the safety of the sexual body; the right to sexual privacy; right to sexual pleasure; right to sexual expression; right to sexual association; right to free and responsible reproductive choices; the right to sexual information free of discrimination (RIOS, 2006, p. 71-100).

They are rights that, although they receive distinct names, they are intrinsically related to the sexual experience, generally composing the category of the rights of sexuality. Any human being thus has the right to have his/her sexual privacy respected, which can be expressed, for example, from the choices that involve his/her own body, his/her appearance, his/her behavior, his/her interpersonal relations and consensual sexual practices without the invasive and arbitrary interference of the State or the society.

Although the country's rules, especially the constitutional ones, do not specifically address the theme, the opening of the catalog of fundamental rights, foreseen in its art. $5, \S 2{ }^{16}$ allows for the recognition of new rights that meet the social demands, in order to protect the broadest range of possible situations.

This positioning represents the concern that exists with the rigidity and loss of the institution's effectiveness, created to protect and serve the citizen, so as to avoid the distancing from the normative rule of the reality lived by the society. It's with this axiological-normative basis that the solid foundations for the recognition of the right to human sexuality is protected, as part of the catalog of fundamental rights, which is supported not only by the regime and principles accepted by the Federal Constitution,

But also as a consequence of international treaty standards ratified by Brazil. In that sense, in 1997, the XIII Sexology Congress in Valencia, Spain, the World Association for Sexual Health proclaimed the Declaration of Sexual Rights, which devoted particular attention to the free development of the personality, as well as a person's freedom, including his/her sexuality. ${ }^{17}$

The United Nations High Commissioner for Human Rights also establishes legal obligations for the member States regarding the LGBTQ community, since they consider that the rights of sexuality are a guarantee for the individual to develop all of his/her sexual potentialities, which encompasses autonomy and sexual health (UNITED NATIONS HUMAN 
RIGHTS, 2013, p. 7). It's the recognition of equal respect without distinction, the diversity of sexual manifestations and the access to all goods necessary for life in society, focusing mainly on the reality of the LGBTQ population as a vulnerable minority.

As can be seen, the rights of sexuality refer to individual rights, which, when analyzed from the standpoint of fundamental rights, are listed as rights of the first dimension, as is the case with the rights to liberty and equality, encompassing protection for both conduct, and identity, because freedom encompasses sexual freedom along with the right to equal treatment beyond sexual oneness.

For such, Maria Berenice Dias argues that the recognition of sexuality as a human condition is indispensable, without which the individual cannot feel fulfilled, and belong to the individual's personal liberties, since "[...] it is a natural right which accompanies the human being from his birth, once it stems from his/her own nature" ${ }^{18}$ (DIAS, 2004, 32).

Still, the rights of sexuality are also affirmed as rights of the personality, considering that, according to Margarida Lima Rego, its exercise:

[...] concerns the person's life, his/her physical and psychological health, his/her physical and psychological freedom and integrity, his/her intimacy; because it is a right that protects an indispensable part of the person; and finally, because such right represents an indispensable condition for attaining its purpose or the interests in the life of the human person. (REGO, 2009, p. 6). ${ }^{19}$

Thus, rights are qualified as absolute, which are imposed onto others erga omnes or towards everyone; as general, since they belong to any human being, as part of the minimum and indispensable core of the legal sphere of each person and as irrevocable and nontransferable.

It's indivisible, therefore, to think about sexuality without its incidence on the physical, psychic and moral formation of the human being. The essentiality that underlies the rights of sexuality makes it impossible to deny them as rights of personality, since the sexual expression profoundly affects the development of the personality, which is why denying the experience, the values and the sexual diversities represents the denial of the own humanity of the person.

Regarding this subject, Jaqueline Bergara Kuramoto et. al. say that "[...] sexuality and human dignity are directly related to the quality of life and well-being of people, who seek happiness and well-being"20 (KURAMOTO; ZOLA; MIRANDA, 2004).

Therefore, to admit sexuality as an essential element of the existential project of any person is to encourage not only the consolidation of a plural, free and democratic society, but also the personal fulfillment of each individual.

From this perspective, Roger Raupp Rios explains that the right to sexuality should:

[...] to provide legal protection and promotion of freedom and diversity without focusing on identities or merely tolerated behaviors or to be limited to situations of female social vulnerability and its sexual manifestations. It is necessary to invoke principles that, while ensuring the greatest possible level of freedom and equal dignity, it creates a label-free or disparaging space for issues related to homosexuality, bisexuality, transgender, prostitutes. (RIOS, 2006, p. 71-100). ${ }^{21}$ 
From then on, guaranteeing a free exercise of sexuality translates into respect for the private autonomy of sexual minorities, given that it gives the individual the right of selfdetermination, that is, "to determine autonomously his or her own destiny, making choices that concern his or her own life and human development, as well as [...] defining his/her sexual orientation"22 (MARMELSTEIN, 2011, p. 106-107).

In the words of Elimar Szaniawski, sexual self-determination, composed of individuality and more specifically a person's sexuality, integrates the specificities perceived and developed by a person through his/her self-development and perception, as well as through external influences such as education (SZANIAWSKI, 2005, p. 62-64). After all, it is a freedom that gives the person the power to decide on his or her own life and make choices, because without the exercise of human sexuality, the human race itself is not realized, it lacks freedom, which is a fundamental right.

Because they are characterized as fundamental rights as well as of personality, sexuality rights are faced with the prerogative of non-discrimination, which establishes the creation of effective material and social conditions so that sexual diversity can prevail not only in relation to the State, but also with respect to civil society.

This is what Pierre Rosanvallon points out when saying that the emergence of a society full of singularities means, above all, to enable the subjects to be inclusive instruments in their singularities, which would obligatorily lead to a re-elaboration of public policies and effective, adequate and accessible measures of educational, legislative and judicial bias (ROSANVALLON, 1998, pp. 323-324). If they are violated, everyone has the right to have access to justice, reparation, retraction, indemnification and the guarantee that the damage suffered will not be repeated.

\section{Conclusion}

With the re-personalization of the law, having as principle the dignity of the person, the individual is valued against any violation of what can be conceived as a guarantee or right, recognizing the human being as its sole and final recipient, regardless of sex, race, religion, physical, sexual and/or mental condition.

Within this perspective we have human sexuality, which is a central element of the life of any subject, which integrates the construction of his/her life from before birth until after his death. In its complexity, it encompasses the whole intimate aspect and what's exposed, that is, the way he/she perceives and feels about him/herself, as well as the way society views him/her.

It encompasses questions regarding identity, the psychological, morality, culture, economy, policies, among others. Because it is so immanent to its owner, the sexual manifestation is demonstrated with a fundamental right and personality, since it composes and influences the structure of its personality. In addition, it is a right that unfolds in innumerable other correlates, such as sexual freedom, sexual autonomy, sexual identity, among others, as well as being linked, in a generic way, to rights of honor, intimacy, freedom and equality.

By transcending the historical-cultural standardization of heteronormativity, sexuality goes beyond rigid roles of what is popularly conceived as sex, gender, gender identity and affective-sexual orientation, which is why its conceptualization must be plural and unrestricted for some even understanding because the sexual values are flexible and in constant mutation.

\section{References}

101 Revista Brasileira de Direito Animal, e -issn: 2317-4552, Salvador, volume 15, n. 02, p.79-93, Mai - Ago 2020 
AMARAL, Vera Lúcia do. Psicologia da educação. Natal: EDUFRN, 2007.

BORBA, Rodrigo; OSTERMANN, Ana Cristina. Gênero ilimitado: a construção discursiva da identidade travesti discursiva da identidade travesti discursiva da identidade travesti através da manipulação do através da manipulação do sistema de gênero gramatical sistema de gênero gramatical sistema de gênero gramatical. Revista Feminista. Florianópolis, v. 16, n. 2, p. 409-432, 2008.

BRITO, Paulo Juaci de Almeida. Sexualidade como direito de personalidade: três planos de manifestação. A Leitura: Caderno da Escola Superior de Magistratura do Estado do Pará, Belém, v. 5, n. 8, p. 17-40, 2012.

CÂMARA, Cristina. Cidadania e Orientação Sexual: A Trajetória Política do Triangulo Rosa. Rio de Janeiro: Academia Avançada, 2002.

CAMPOS, Vera Felicidade de Almeida. Sexualidade humana: aspectos psicológicos. Boletim do SBEM, jul./set. de 1999.

CARDIN, Valeria Silva Galdino; SEGATTO, Antonio Carlos; CAZELATTO, Caio Eduardo Costa. O exercício ilegítimo do discurso de ódio homofóbico sob a ótica da sexualidade e da dignidade humana. Revista Jurídica - Unicuritiba, v. 1, n. 46, p. 90-118, 2017. Available in:

revista.unicuritiba.edu.br/index.php/RevJur/article/view/2001. Access in: 10 fev. 2019.

CAZELATTO, Caio Eduardo Costa; CARDIN, Valéria Silva Galdino. Das restrições à liberdade de expressão frente à violação dos direitos das minorias sexuais pelo discurso de ódio. Revista Conpedi Law Review, v. 3, n. 2, p. 56-83, dez. 2017. ISSN 2448-3931. Available in:

http://portaltutor.com/index.php/conpedireview/article/view/446. Access in: 27 jan. 2019.

CAZELATTO, Caio Eduardo Costa; CARDIN, Valéria Silva Galdino. Dos impactos do discurso de ódio homofóbico no ambiente informático. Revista de Direito, Governança e Novas Tecnologias, Brasília, v. 3, n. 1, p. 1-22, jan/jun. 2017. ISSN 2526-0049. Available in:

www.indexlaw.org/index.php/revistadgnt/article/view/1947/pdf. Access in: 8 fev. 2019.

CAZELATTO, Caio Eduardo Costa; CARDIN, Valéria Silva Galdino. Dos aspectos jurídicos da pedofilia: por uma intervenção estatal digna e efetiva ao pedófilo. Revista Quaestio luris, Rio de Janeiro, v. 10, n. 04, p. 2863-2876, 2017. ISSN 1516-0351. Available in: www.e-

publicacoes.uerj.br/index.php/quaestioiuris/article/view/26686/21927. Access in: 28 jan. 2019.

CAZELATTO, Caio Eduardo Costa; CARDIN, Valéria Silva Galdino. Homophobic hate discourse in the information society: from the impacts to the balance of the computer environment and to human sexuality. Revista do Direito UNISC, Santa Cruz do Sul, v. 1, n. 51, p. 176-191, jan. 2017. ISSN 1982-9957. Available in: https://online.unisc.br/seer/index.php/direito/article/view/8742. Access in: 28 jan. 2019.

CAZELATTO, Caio Eduardo Costa; CARDIN, Valéria Silva Galdino. Discurso de ódio e minorias sexuais. Rio de Janeiro: Lumen Juris, 2018. 
CAZELATTO, Caio Eduardo Costa; CARDIN, Valéria Silva Galdino. O discurso de ódio homofóbico no Brasil: um instrumento limitador da sexualidade humana. Revista Jurídica Cesumar Mestrado, Maringá, v. 16, n. 3, p. 919-938, set./dez. 2016. ISSN 2176-9184. Available in: periodicos.unicesumar.edu.br/index.php/revjuridica/article/view/5465/2893. Access in: 16 fev. 2019.

CAZELATTO, Caio Eduardo Costa; MORENO, Michel Henrique Timóteo. Da Sociedade da Informação frente ao Acesso à Internet como um Direito Fundamental de Personalidade. Revista de Direito, Governança e Novas Tecnologias, Brasília, v. 2, n. 1, p. 92-112, jan./jun. 2016. Available in: http://www.conpedi.org.br/publicacoes/y0ii48h0/k778x2oo/zgqAj9dBszMD3c0L.pdf. Access in: 22 fev. 2019.

DIAS, Maria Berenice. Conversando sobre a homoafetividade. Porto Alegre: Livraria do Advogado, 2004.

DINIZ, Maria Helena. O Atual Estágio do Biodireito. 2. ed. São Paulo: Saraiva, 2002.

ENELLI, Sílvio José. A Instituição total como agência de produção de subjetividade na sociedade disciplinar. Estudos de Psicologia (Campinas), Campinas, v. 21, n. 3, p. 237-252, dez. 2004.

FAGUNDES, Tereza Cristina. Ensaios sobre Educação, Sexualidade e Gênero. Salvador: Helvécia, 2005.

FREUD, Sigmund. Três ensaios sobre a teoria da sexualdiade. Lisboa: Livros do Brasil, 1982.

GIDDENSM Anthony. A transformação da intimidade: sexualidade, amor e erotismo nas sociedades modernas. Trad. Magda Lopes. São Paulo: Fundação Editora da UNESP, 1992.

GOULART, Vincent Pereira; NARDI, Henrique Caetano. Trajetórias de vida de pessoas Igbtt e transformações no dispositivo da sexualidade. In: XXVII Salão de Iniciação Científica da UFRGS. Porto Alegre: UFRGS, 2015.

GROSSI, Miriam Pillar. Identidade de gênero e sexualidade. Estudos de Gênero: Cadernos de área n. 9. Goiânia: UCG, 2000

JESUS, Jaqueline Gomes de. Orientações sobre a população transgênero: conceitos e termos. Brasília: Autor, 2012.

KURAMOTO, Jaqueline Bergara; ZOLA, Regina Célia; MIRANDA, Juranda Maia de. Pessoa humana e sexualidade. In: VIEIRA, Tereza Rodrigues. Bioética e Sexualidade. São Paulo: Jurídica Brasileira, 2004.

LAWLOR, Robert. Honrando a terra: a nova sexualidade masculina. São Paulo: Interação, 1991.

LEÓN, Fernando Muñoz. Direitos humanos e diversidade sexual: contexto geral. In: Direitos humanos dos grupos vulneráveis. Barcelona: Universitat Pompeu Fabra, 2014.

103 | Revista Brasileira de Direito Animal, e -issn: 2317-4552, Salvador, volume 15, n. 02, p.79-93, Mai - Ago 2020 
LIMA, Isabel Maria Sampaio Oliveira; TORALLES, Maria Betânia Pereira; FRASER, Roberta Tourinho Dantas. Intersexo e direito da criança à informação na família: superando o silêncio e integrando a identidade. In: MESSEDER, Suely Aldir; MARTINS, Marco Antônio Matos. (Org.) Enlaçando sexualidades. Salvador: Eduneb, 2010, v. 1.

LOURO, Guacira Lopes (org.). O corpo Educado: pedagogias da sexualidade. 3. ed. Belo Horizonte: Autêntica, 2010.

MARMELSTEIN, George. Curso de Direitos Fundamentais. 3. ed. São Paulo: Atlas, 2011.

OLIVEIRA, Marta Kohl. Vygotsky: aprendizado e desenvolvimento um processo sócio-histórico. São Paulo: Scipione, 1993.

ORGANIZAÇÃO DAS NAÇÕES UNIDAS. Declaração Universal dos Direitos Humanos. 1948.

PELUCIO, Larissa. Três casamentos e algumas reflexões: notas sobre conjugalidade envolvendo travestis que se prostituem. Revista Feminista, Florianópolis, v. 14, n. 2, p. 522-534, 2006.

PRINCÍPIOS DE YOGYAKARTA. Princípios sobre a aplicação da legislação internacional de direitos humanos em relação à orientação sexual e identidade de gênero. 2006. Available in:

www.clam.org.br/uploads/conteudo/principios_de_yogyakarta.pdf. Access in: 01 dez. 2018.

REGO, Margarida Lima. $O$ direito de sexualidade. Lisboa: Faculdade de Direito da Universidade de Lisboa, 2009.

RIOS, Roger Raupp. Para um direito democrático da sexualidade. Revista Horizonte Antropológico. Porto Alegre, v. 12, n. 26, p. 71-100, 2006.

ROCHA, Francielle Lopes; CARDIN, Valéria Silva Galdino. Do discurso do ódio contra as minorias sexuais como um instrumento de exclusão social. In: SIQUEIRA, Dirceu Pereira; AMARAL, Sérgio Tibiriçá (Org.). Democracia, Liberdade e Justiça Social: Fundamentos para uma teoria jurídica do reconhecimento. Birigui: Boreal, 2015.

ROSA, Leitícia Carla Baptista; CAZELATTO, Caio Eduardo Costa Cazelatto. Do direito fundamental à realização do projeto homoparental por meio da utilização da reprodução humana assistida. Anais do XXII Encontro Nacional do CONPEDI, Curitiba, maio/jul., 2013. Available in: http://www.publicadireito.com.br/artigos/?cod=7d4ba7006351436c. Access in: 17 fev. 2019.

ROSANVALLON, Pierre. A nova questão social: repensando o Estado Providência. Trad. Sérgio Barth. Brasília: Instituto Teotônio Vilela, 1998.

SILVA JUNIOR, Jonas Alves da. Uma explosão de cores: sexo, sexualidade, gênero e diversidade. In: VIEIRA, Tereza Rodrigues (Org.). Minorias Sexuais: Direitos e Preconceitos. Brasília: Consulex, 2012.

SIMPSON, Keila. Travestis: entre a atração e a aversão. In: VENTURI, Gustavo; BOKANY, Vilma (Orgs.). Diversidade sexual e homofobia no Brasil. São Paulo: Fundação Perseu Abramo, 2011.

104 | Revista Brasileira de Direito Animal, e -issn: 2317-4552, Salvador, volume 15, n. 02, p.79-106, Mai - Ago 2020 
SIVERINO-BAVIO, Paula. Diversidad sexual y derechos humanos: El reconocimiento de las personas sexualmente diversas como sujetos plenos de derecho. Revista General de Derecho Constitucional, La Rioja, Espanha, n. 19, p. 222-243, 2014.

SZANIAWSKI, Elimar. Direitos da personalidade e sua tutela. São Paulo: Revista dos Tribunais, 2005.

TOURRAINE, Alan. Igualdade e diversidade: o sujeito democrático. Trad. de Modesto Florenzano. São Paulo: EDUSC, 1998.

UNITED NATIONS HUMAN RIGHTS, Office of the Hight Commissioner. Nascidos livres e iguais: orientação sexual e identidade de gênero no regime internacional de Direitos Humanos. Brasília: OHC, 2013. Available in: http://www.ohchr.org/Documents/Publications/BornFreeAndEqualLowRes_Portuguese.pdf. Access in: 17 jan. 2019.

VIEIRA, Tereza Rodrigues. Nome e sexo: mudanças no registro civil. São Paulo: Atlas, 2012.

VIEIRA, Tereza Rodrigues. O impacto da genética sobre a vida do transexual: aspectos bioéticos e jurídicos. Anais Eletrônicos do Encontro de Bioética do Paraná, Bioética início da vida em foco. Curitiba: Champagnat, 2009.

WAS, World Association for Sexual Health. Declaração dos Direito Sexuais. 2013. Available in: http://www.worldsexology.org/wp-content/uploads/2013/08/DSR-Portugese.pdf. Acess in: 05 jan. 2019.

WEEKS, Jefrey. O Corpo e a Sexualidade. In LOURO, Guacira Lopes (org.). O corpo educado: pedagogias da sexualidade. 2. ed. São Paulo: Autêntica, 2001.

WORLD HEALTH ORGANIZATION. Sexual and reproductive health: Gender and human rights. 2002. Available in: www.who.int/reproductivehealth/topics/gender_rights/sexual_health/en/. Access in: 01 jan. 2019.

\section{Notas de Referência}

\footnotetext{
${ }^{1}$ Original text: "[...] um aspecto maleável do 'eu', um ponto de conexão entre o corpo, a autoidentidade e as normas sociais".

2 Original text: "[...] reduz nem a uma forma de consumo, nem a um erotismo que seja seu oposto, é um chamamento do indivíduo a si mesmo, à sua livre criação, ao seu prazer, à sua felicidade".

${ }^{3}$ Original text: "[...] rede complexa de organização social que organiza e modela os corpos e os comportamentos individuais".

${ }^{4}$ Original text: "[...] um aspecto central do ser humano em toda a vida e abrange sexo, identidade e papeis de gênero, orientação sexual, erotismo, prazer, intimidade e reprodução".

5 Original text: "[...] capacidad del hombre de autoconstruirse estimando lo que lo define como ser verdaderamente humano, el basamento de su dignidad, valor fundante de todos sus derechos".

${ }^{6}$ Original text: "[...] às características biológicas que definem seres humanos como homem ou mulher".

${ }^{7}$ Original text: "[...] anatômico-biológico ganhou uma condição tão importante que o sexo transformou-se em uma senha, talvez até em um ícone, para a dimensão sexual humana, para a sexualidade humana".
} 
${ }^{8}$ Original text: “[...] tamanho das suas células reprodutivas (pequenas: espermatozoides, logo, macho; grandes: óvulos, logo, fêmea), e só".

${ }^{9}$ Original text: "biologicamente, isso não define o comportamento masculino ou feminino das pessoas: o que faz isso é a cultura".

${ }^{10}$ Original text: "[...] à tradição codificada, às práticas cotidianas, e às propostas de inovação cultural elaboradas pelos grupos sociais".

${ }^{11}$ Original text: "[...] o indivíduo realiza ações externas que serão interpretadas pelas pessoas ao seu redor, de acordo com os significados culturalmente estabelecidos. A partir dessa interpretação é que será possível para o indivíduo atribuir significados a suas próprias ações e desenvolver processos psicológicos internos que podem ser interpretados por ele próprio a partir dos mecanismos estabelecidos pelo grupo cultural e compreendidos por meio dos códigos compartilhados pelos membros desse grupo".

${ }^{12}$ Original text: "[...] autopercepção do sujeito; com a coincidência ou divergência entre a percepção que este tem de si próprio e a identidade que a sociedade - ou os seus pais e os seus médicos, em nome dela - lhe atribuiu".

${ }^{13}$ Original text:

${ }^{14}$ Original text: "As travestis são pessoas que nascem com um sexo genital e que procuram inserir em seus corpos símbolos do que é socialmente sancionado para o binarismo de gêneros, sem, contudo, desejarem extirpar sua genitália, com a qual, geralmente, convivem sem grandes conflitos".

${ }^{15}$ Original text: "[...] uma referência à capacidade de cada pessoa de ter uma profunda atração emocional, afetiva e/ou sexual por indivíduos de gênero diferente, do mesmo gênero ou de mais de um gênero".

${ }^{16}$ The rights and guarantees expressed in this Constitution do not exclude others arising from the regime and the principles adopted, or from international treaties to which the Federative Republic of Brazil is a party.

17 "Art. 2. All human beings may invoke the rights and freedoms set forth in this Declaration without distinction of any kind, such as race, color, sex, language, religion, political view or other." (UNITED NATIONS ORGANIZATION, 1948).

${ }^{18}$ Original text: "[...] é um direito natural que acompanha o ser humano desde seu nascimento, pois decorre de sua própria natureza".

${ }^{19}$ Original text: "[...] incide sobre a vida da pessoa, sobre a sua saúde física e psicológica, sobre a sua liberdade e integridade física e psicológica, sobre a sua intimidade; porque é um direito que protege uma parte imprescindível da pessoa humana; e porque, finalmente, tal direito representa uma condição indispensável para a realização dos fins ou interesses da vida da pessoa humana.".

${ }^{20}$ Original text: "[...] sexualidade e dignidade humana estão diretamente relacionadas à qualidade de vida e bemestar das pessoas, que buscam a felicidade e uma vida boa".

${ }^{21}$ Original text: "[...] propiciar proteção jurídica e promoção da liberdade e da diversidade sem fixar-se em identidades ou condutas meramente toleradas ou limitar-se às situações de vulnerabilidade social feminina e suas manifestações sexuais. É necessário invocar princípios que, velando pelo maior âmbito de liberdade possível e igual dignidade, criem um espaço livre de rótulos ou menosprezos a questões relacionadas à homossexualidade, bissexualidade, transgêneros, profissionais do sexo".

${ }^{22}$ Original text: "[...] determinar autonomamente o seu próprio destino, fazendo escolhas que digam respeito à sua vida e ao seu desenvolvimento humano, como [...] definir sua orientação sexual". 